Gorontalo Accounting Journal
https://jurnal.unigo.ac.id/index.php/gaj
Vol. 4, No. 2, October 2021
P-ISSN: 2614-2074, E-ISSN: 2614-2066
Gatolontialo
Nationally Accredited Journal, Decree No.36/E/KPT/2019 Sinta 4

\title{
Pengaruh Perubahan Tarif Pajak Penghasilan, Struktur Modal Dan Kebijakan Dividen Terhadap Harga Saham
}

\author{
Puji Rahayu' ${ }^{1}$, Ahmad Yani ${ }^{2}$ \\ Universitas Islam Kadiri, Jalan Sersan Suharmadji No. 38 Kediri, Jawa Timur/Indonesia \\ Email: pujirahayu@uniska-kediri.ac.id¹, ahmadyani@uniska-kediri.ac.id²
}

Citation: Rahayu, P. \& Yani, A. (2021). Pengaruh Perubahan Tarif Pajak Penghasilan, Struktur Modal Dan Kebijakan Dividen Terhadap Harga Saham. Gorontalo Accounting Journal 4 (2), 184-196. DOI: 10.32662/gaj.v4i2.1732

\section{Artikel info}

\section{Artikel history:}

Received: 21-08-2021

Revised: 06-10-2021

Accepted: 16-10-2021

\begin{abstract}
The purpose of this study is to analyze the effect of changes in income tax rates according to PP no. 30 of 2020, capital structure and dividend policy on stock prices in manufacturing companies in the Food and Beverage sector listed on the Indonesia Stock Exchange in 2016 -2020. This type of research uses descriptive quantitative. The population in this study were 30 companies. The sampling technique in this study was purposive sampling, so that a sample of 15 data from 3 companies was obtained for 5 years. Methods of data analysis using multiple linear regression analysis with the help of SPSS application. The results of the partial analysis show that the tax rate and dividend policy have no effect on stock prices. While the capital structure has a positive influence on stock prices. However, simultaneously stock prices are affected by changes in income tax rates, capital structure, and dividend policy. Based on the results of the study, it can be concluded that the high and low tax rates are not able to affect stock prices. The higher the capital structure will be followed by an increase in stock prices. While the dividend policy can not affect changes in stock prices.
\end{abstract}

Abstrak. Tujuan dari penelitian ini untuk menganalisis pengaruh perubahan tarif pajak penghasilan sesuai PP No. 30 Tahun 2020, struktur modal dan kebijakan dividen terhadap harga saham pada perusahaan manufaktur sektor Food And Beverage yang terdaftar di BEI tahun 2016 -2020. Jenis penelitian ini menggunakan deskriptif kuantitatif. Populasi dalam penelitian ini adalah 30 perusahaan. Teknik pengambilan sampel dalam penelitian ini adalah purposive sampling, sehingga di dapat sampel sebanyak 15 data dari 3 perusahaan selama 5 tahun. Metode analisis data menggunakan teknik analisis regresi linear berganda dengan dibantu aplikasi SPSS. Hasil analisis secara parsial menunjukkan bahwa tarif pajak dan kebijakan deviden tidak berpengaruh terhadap harga saham. Sedangkan struktur modal memiliki pengaruh postif terhadap harga saham. Namun secara simultan harga saham dipengaruhi oleh perubahan tarif pajak penghasilan, stuktur modal, dan 


\section{Keywords:}

Tarif Pajak,

Struktur Modal;

Harga Saham kebijakan dividen. Berdasarkan hasil penelitian dapat diberikan kesimpulan bahwa tinggi rendahnya tarif pajak tidak mampu mempengaruhi harga saham. Semakin tinggi struktur modal akan diikuti dengan kenaikan harga saham. Sedangkan kebijakan dividen tidak dapat mempengaruhi perubahan harga saham.

Coresponden author:

Email: pujirahayu@uniska-kediri.ac.id

\section{Pendahuluan}

Pandemi Corona Virus Disease 2019 (COVID-19) seperti saat ini, telah mengganggu aktivitas perekonomian sebagian besar Negara-negara di seluruh dunia, tak terkecuali Indonesia. Pertumbuhan ekonomi Indonesia diperkirakan telah mengalami penurunan 4\% atau lebih rendah (Kementerian Sekretariat Negara Republik Indonesia, 2020a). Terganggunya aktivitas ekonomi ini akan berimplikasi pada operasional perusahaan, sehingga manajemen perusahaan harus memiliki perencanaan yang cerdas untuk membiayai kegiatan operasional perusahaannya, baik dalam jangka pendek, jangka menengah maupun jangka panjang. Demi mewujudkan hal tersebut manajemen perusahaan dapat memanfaatkan beberapa kebijakan yang telah diberikan oleh pemerintah. Menurut (Suandy, 2016) melalui kebijakan dapat menjadi acuan untuk menyesuaikan kondisi perekonomian suatu Negara. Salah satu kebijakan tersebut dalam bidang perpajakan yaitu tentang perubahan tarif $\mathrm{PPh}$.

Perubahan tarif Pajak Penghasilan (PPh) tertuang dalam Peraturan Pemerintah No. 30 Tahun 2020 tentang Penurunan Tarif PPh Bagi Wajib Pajak (WP) Badan Dalam Negeri yang Berbentuk Perseroan Terbuka. Peraturan Pemerintah ini selanjutnya di sebut dengan PP No. 30 Tahun 2020. Penurunan tarif ini mulai berlaku pada 19 Juni 2020, yang mana sebelumnya diatur dalam Undang-Undang No. 36 tahun 2008 tarif PPh badan sebesar 25\%, semenjak diberlakukannya PP No. 30 Tahun 2020 tarif PPh badan turun menjadi $22 \%$ yang berlaku pada tahun pajak 2020 dan 2021, sedangkan pada tahun 2022 tarifnya turun lagi menjadi 20\% (Kementerian Sekretariat Negara Republik Indonesia, 2020b).

Tabel 1. Tarif PPh WP Badan dan Bentuk Usaha Tetap

\begin{tabular}{|c|c|c|c|}
\hline $\begin{array}{l}\text { Tahun } \\
\text { Berlaku }\end{array}$ & Keterangan & Tarif & Dasar Hukum \\
\hline 2009 & Seluruh WP Badan dan BUT & $28 \%$ & $\begin{array}{l}\text { Pasal } 17 \text { ayat } 1 \text { UU } \\
\text { PPh No. } 36 \text { Th } 2008\end{array}$ \\
\hline \multirow[t]{2}{*}{$\begin{array}{l}2010- \\
2019\end{array}$} & $\begin{array}{l}\text { Saham tidak dijual di BEI } \\
\text { atau < } 40 \% \text { sahamnya } \\
\text { diperdagangkan di BEI }\end{array}$ & $25 \%$ & $\begin{array}{l}\text { Pasal } 17 \text { ayat }(2 a) \text { UU } \\
\text { PPh No. } 36 \text { Tahun } \\
2008\end{array}$ \\
\hline & $\begin{array}{l}\text { Saham dijual di BEI paling } \\
\text { sedikit } 40 \%\end{array}$ & $\begin{array}{l}5 \% \text { lebih rendah } \\
\text { dari yang } \\
\text { seharusnya }\end{array}$ & $\begin{array}{l}\text { Pasal } 17 \text { ayat }(2 \mathrm{~b}) \text { UU } \\
\text { PPh No. } 36 \text { Tahun } \\
2008\end{array}$ \\
\hline \multirow[t]{2}{*}{$\begin{array}{l}2020- \\
2021\end{array}$} & $\begin{array}{l}\text { Saham tidak dijual di BEI } \\
\text { atau < }<0 \% \text { sahamnya } \\
\text { diperdagangkan di BEI }\end{array}$ & $22 \%$ & $\begin{array}{l}\text { Pasal } 2 \text { huruf a PP No. } \\
30 \text { Tahun } 2020\end{array}$ \\
\hline & $\begin{array}{l}\text { Saham dijual di BEI paling } \\
\text { sedikit } 40 \%\end{array}$ & $\begin{array}{l}\text { 3\% lebih rendah } \\
\text { dari yang } \\
\text { seharusnya }\end{array}$ & $\begin{array}{l}\text { Pasal } 3 \text { ayat } 1 \text { PP No. } \\
30 \text { Tahun } 2020\end{array}$ \\
\hline
\end{tabular}




\begin{tabular}{llll}
\hline 2022 & $\begin{array}{l}\text { Saham tidak dijual di BEI } \\
\text { atau }<40 \% \text { sahamnya } \\
\text { diperdagangkan di BEI }\end{array}$ & $20 \%$ & $\begin{array}{l}\text { Pasal } 2 \text { huruf b PP No. } \\
\text { 30 Tahun 2020 }\end{array}$ \\
\cline { 2 - 3 } & $\begin{array}{l}\text { Saham dijual di BEI paling } \\
\text { sedikit 40\% }\end{array}$ & $\begin{array}{c}\text { 3\% lebih rendah } \\
\text { dari yang } \\
\text { seharusnya }\end{array}$ & $\begin{array}{l}\text { Pasal 3 ayat 1 PP No. } \\
\text { 30 Tahun 2020 }\end{array}$ \\
\hline
\end{tabular}

Sumber : (Kementerian Sekretariat Negara Republik Indonesia, 2008, 2020b)

Tarif pajak yaitu tarif yang digunakan untuk menentukan besarnya pajak yang harus dibayar (Rahayu, 2019). Semakin kecil pajak yang dibayarkan, perusahaan akan merasa semakin sejahtera (Alfandia, 2018). Tarif pajak ini merupakan salah satu bahan pertimbangan para investor untuk menanamkan sahamnya. Karena tarif pajak memiliki peran dalam upaya meningkatkan harga saham (Suripto, 2019). Menurut (Faisal, 2012) investor akan memindahkan danadana ke negara -negara yang pajaknya lebih rendah. Dengan kata lain investor akan membeli saham pada perusahaan yang berada pada Negara yang memiliki tarif pajak lebih rendah. Melalui penjualan saham, perusahaan memperoleh modal sendiri, selain dari modal asing atau pinjaman(Musthafa, 2017). Perimbangan antara kedua modal tersebut disebut struktur modal.

Struktur modal merupakan proporsi finansial yang terdiri dari modal asing dan modal sendiri yang digunakan sebagai sumber pembiayaan perusahaan (Febriani \& Kristanti, 2020). Struktur modal mempunyai efek langsung terhadap posisi finansial (Widanastiti \& Rahayu, 2020). Salah satu tujuan manajemen modal yaitu untuk memaksimalkan nilai kekayaan para pemegang saham. Nilai tersebut dapat dilihat dari perkembangan harga saham (Harmono, 2018). Teori struktur modal pada perkembangannya terus mengalami perbaikan-perbaikan. Menurut (Kamaludin \& Indriani, 2012) ada 4 teori struktur modal yaitu : pendekatan laba bersih atau net income (NI), pendekatan laba operasi bersih atau net operating income (NOI), pandangan tradisional, dan pendekatan klasik oleh teori Franco Modigliani dan Merton Miller (MM). Teori Modigliani-Miller awalnya menjelaskan struktur modal tanpa efek pajak, kemudian dilakukan penelitian lagi dan menjelaskan struktur modal dengan efek pajak (Utami \& Widanaputra, 2017). Menurut (Sulindawati, Yuniarta, \& Purnamawati, 2017) Tingginya risiko yang akan dihadapi oleh perusahaan atas penentuan kebijakan struktur modal berdampak pada penurunan harga saham, tetapi dengan meningkatnya tingkat pengembalian yang diharapkan akan meningkatkan harga saham tersebut. Selain itu struktur modal merupakan salah satu faktor yang mempengaruhi kebijakan dividen (Verawati \& Puspitawati, 2018).

Kebijakan dividen merupakan persentase laba yang dibayarkan kepada para pemegang saham dalam bentuk dividen tunai dan penjagaan stabilitas laba ditahan yang digunakan sebagai investasi perusahaan(Viriany \& Kristian, 2021). Kekayaan pemegang saham dapat dimaksimalkan menggunakan kebijakan dividend pay out ratio (DPR) atau rasio pembayaran dividen (Harmono, 2018). Pemegang saham atau investor lebih memilih saham dari perusahaan yang membagikan dividen secara teratur bila tarif $\mathrm{PPh}$ atas dividen lebih rendah atau sama dengan tarif pajak atas capital gains, sebaliknya bila tarif pajak atas dividen lebih tinggi dari capital gains maka investor akan lebih suka menerima capital gains daripada dividen. Dengan kata lain investor akan menjual saham yang dimilikinya, maka ada beberapa investor yang tidak suka perusahaan yang melakukan pembayaran dividen secara besar-besaran karena akan dikenakan pajak yang besar (Husnan \& Pudjiastuti, 2018). Kebijakan dividen memberikan informasi kepada pihak yang berkepentingan terhadap kinerja perusahaan, 
investasi yang dilakukan perusahaan menentukan laba masa depan. Semakin dividen tunai meningkat maka harga saham juga meningkat, sebaliknya ketika dividen tunai menurun maka akan diikuti dengan penurunan harga saham (Pranata, Purnamawati, \& Adiputra, 2015).

Harga saham merupakan harga suatu saham pada pasar yang sedang berlangsung di bursa efek. Harga saham dapat dipengaruhi oleh penjamin emisi dan emiten (Neni, 2018). Sedangkan saham sendiri merupakan tanda bukti penyertaan kepemilikan modal atau dana pada suatu perusahaan, tercantum dengan jelas nilai nominal, nama perusahaan di ikuti dengan hak dan kewajiban yang dijelaskan kepada setiap pemegangnya(Fahmi, 2018). Pemegang saham atau investor sebelum memutuskan untuk menginvestasikan dananya harus melakukan beberapa penilaian dengan cermat terhadap emiten. Para investor akan mendasarkan keputusan investasinya pada informasi yang diperolehnya termasuk informasi laporan keuangan(Sulia, 2017). Laporan keuangan perusahaan akan mengalami perubahan secara terus-menerus seiring dengan kondisi perusahaan yang telah dialami. Perubahan tersebut akan mempengaruhi pengambilan keputusan dari struktur modal. Selain itu Bila tarif $\mathrm{PPh}$ turun maka akan mengurangi $\mathrm{PPh}$ terutang, sehingga laba bersih perusahaan setelah pajak semakin besar dan perusahaan dapat meningkatkan saldo laba. Dari saldo laba tersebut perusahaan dapat mendistribusikan kepada pemegang saham dalam bentuk pembagian dividen(Ayem \& Fatimah, 2018).

Menurut teori Franco Modigliani dan Merton Miller yang dikenal dengan pendekatan MM memperkenalkan model pengaruh leverage terhadap nilai perusahaan jika terdapat pajak pendapatan perseorangan dan pajak perusahaan. Bila pendapatan atas saham terdiri dari deviden dan capital gain, maka rata-rata tertimbang tarif pajak efektif atas deviden dan capital gain akan mempengaruhi nilai perusahaan. Selain itu MM juga menentang pendekatan net income (NI) yang menyatakan bahwa nilai perusahaan akan meningkat bila proporsi hutang semakin besar. Hal ini disebabkan oleh perusahaan memiliki struktur modal yang berbeda, maka akan terjadi proses abritase. Dimana investor akan menjual saham yang memiliki hutang sebagai struktur modalnya. Kemudian membeli saham perusahaan yang tidak memiliki hutang sebagai struktur modalnya, karena harga sahamnya murah(Kamaludin \& Indriani, 2012).

Berbagai hasil penelitian terdahulu terkait perubahan tarif $\mathrm{PPh}$, struktur modal, kebijakan dividen terhadap harga saham sudah banyak dilakukan. Namun hasilnya tidak konsisten, perbedaan jenis usaha dan karakteristik industry bisa mempengaruhi ketidakkonsistenan hasil penelitian tersebut ditambah dengan fenomena yang terjadi seperti sekarang ini pada masa pandemic. Dengan adanya kebijakan terkait pengalihan aktivitas secara daring (dampaknya seperti penutupan kantin sekolah) dan pemberlakuan pembatasan kegiatan masyarakat (PPKM) (berdampak pada pembatasan jam buka mall, toko, café, dan lain sejenisnya). Beberapa perusahaan akan menambah peminjaman dana pada kreditur dan sebagaian perusahaan terpaksa harus melepas saham untuk menambah modal. Hal tersebut sangat mempengaruhi kondisi harga saham perusahaan, tak terkecuali perusahaan manufaktur sektor Food And Beverage. Maka dari itu peneliti tertarik melakukan penelitian tentang bagaimana pengaruh perubahan tarif $\mathrm{PPh}$, struktur modal, kebijakan dividen terhadap harga saham pada perusahaan manufaktur sektor Food And Beverage yang terdaftar di BEI tahun $2016-2020$.

Sedangkan tujuan dari penelitian ini untuk mengetahui dan membuktikan secara empiris pengaruh perubahan tarif pajak sesuai PP No. 30 Tahun 2020, struktur modal, kebijakan dividen terhadap harga saham. Karena terdapat riset 
gap dari hasil penelitian terdahulu. Penelitian yang telah dilakukan oleh (Pranata et al., 2015) dan penelitian tersebut merupakan artikel utama yang menjadi acuan dalam penelitian ini dan peneliti menambahkan satu variabel yang relevan dengan fenomena saat ini terkait harga saham yaitu variabel struktur modal.

Beberapa penelitian memiliki hasil yang berbeda seperti penelitian yang telah dilakukan oleh (Pranata et al., 2015; Suripto, 2019)terkait variabel perubahan tarif $\mathrm{PPh}$ menemukan bahwa tarif pajak berpengaruh positif dan signifikan terhadap harga saham. Namun hasil tersebut berbeda dengan penelitian yang dilakukan oleh (Putra \& Tjaraka, 2016; Soalihin, Susyanti, \& Salim, 2019) yang menyimpulkan bahwa tarif pajak memiliki hubungan negative dan tidak signifikan terhadap harga saham.

Hasil penelitian terdahulu terkait variabel struktur modal yang dilakukan oleh (Hasanuddin, 2020) menunjukan struktur modal yang dihitung dengan rasio Debt to Equity (DER) menunjukan adanya arah pengaruh yang negatif tidak signifikan terhadap harga saham. Sedangkan (Muhonis \& Susanti, 2021) hasil penelitiannya membuktikan DER tidak berpengaruh terhadap harga saham. Berbeda dengan penelitian yang dilakukan oleh (Munira, Merawati, \& Astuti, 2018) menunjukan bahwa DER secara parsial memiliki pengaruh yang berarti terhadap harga saham dan (Estiasih, Prihatiningsih, \& Fatmawati, 2020) dalam penelitiannya menyatakan DER berpengaruh signifikan terhadap harga saham.

Perbedaan hasil penelitian terdahulu terkait variabel kebijakan dividen antara penelitian yang dilakukan oleh (Pranata et al., 2015) menunjukan kebijakan dividen yang diukur menggunakan Dividend Payout Ratio (DPR) berpengaruh positif terhadap harga saham, hasil ini serupa dengan hasil penelitian (Suripto, 2019) selain itu (Silalahi \& Manik, 2019) dan (Estiasih et al., 2020) membuktikan bahwa DPR berpengaruh secara signifikan terhadap harga saham, sedangkan menurut (Mariana, 2016) kebijakan dividen tidak berpengaruh terhadap harga saham.

Berdasarkan penjelasan tersebut dapat dibuat hipotesis penelitian dan kerangka pikir, sebagai berikut :

H1 : Tarif pajak berpengaruh secara signifikan terhadap harga saham

H2 : Struktur Modal berpengaruh secara signifikan terhadap harga saham

H3 : Kebijakan Dividen berpengaruh secara signifikan terhadap harga saham

H4 : Tarif pajak, struktur modal dan kebijakan dividen berpengaruh secara simultan dan signifikan terhadap harga saham.

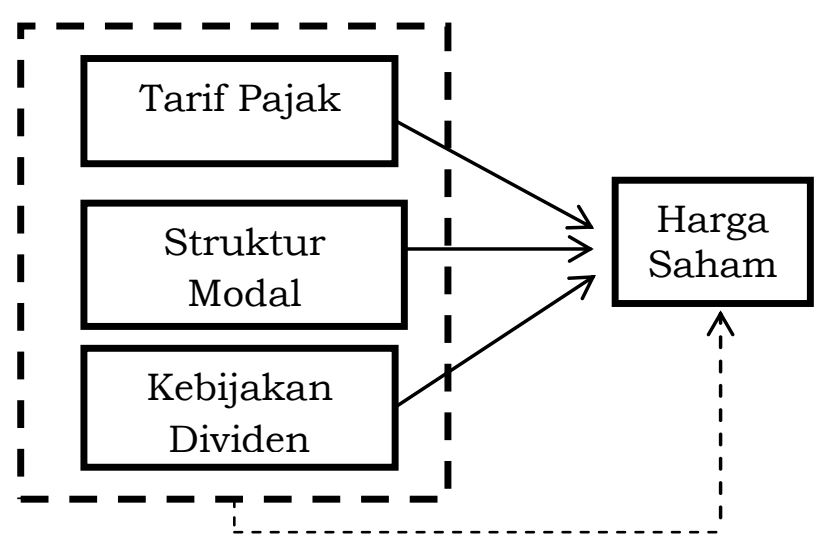

Gambar 1. Kerangka Pikir 
Kebaharuan penelitian ini dibanding dengan penelitian yang sudah banyak dilakukan yaitu penelitian ini membandingkan perubahan tarif pajak mengacu pada PP No. 30 Tahun 2020 dengan UU No. 36 Tahun 2008 dan menggunakan variabel dummy sebagai alat ukurnya. Sedangkan para peneliti terdahulu hanya membandingkan tarif pajak pada UU No. 36 Tahun 2008 dan beban pajak yang dibayar sebagai alat ukurnya. Metode yang digunakan peneliti terdahulu menggunakan Path Analyst sedangkan penelitian ini menggunakan regresi linier berganda. Peneliti terdahulu menggunakan software E-Views 10.0 sedangkan penelitian ini menggunakan software SPSS Versi 23.

Penelitian ini memiliki nilai manfaat bagi perusahaan berupa pentingnya memanfaatkan kebijakan pemerintah terkait perubahan tarif pajak, dengan begitu perusahaan dapat memanfaatkan uang yang seharusnya untuk membayar pajak bisa dialihkan sebagai tambahan modal dalam mengelola perusahaan. Sehingga bisa memperbaiki struktur modal dan memberikan kebijakan dividen kepada pemegang saham. Harapannya hal tersebut bisa meningkatkan nilai perusahaan, sehingga tingkat kepercayaan investor pun semakin tinggi dan harga saham pun juga tinggi.

\section{Metode Penelitian}

Penelitian ini merupakan jenis penelitian kuantitatif dengan data yang digunakan dalam penelitian adalah data sekunder berupa laporan keuangan perusahaan. Populasi dalam penelitian ini adalah seluruh perusahaan manufaktur sektor Food And Beverage yang terdaftar di Bursa Efek Indonesia pada tahun 2016-2020. Metode pengambilan sampel yang digunakan adalah non probability sampling dengan tehnik purposive sampling. Kriteria sampel adalah sebagai berikut :

Tabel 2. Kriteria Sampel Penelitian

\begin{tabular}{|c|c|c|}
\hline No. & Kriteria & Jumlah \\
\hline 1 & $\begin{array}{l}\text { Perusahaan manufaktur sektor food and } \\
\text { beverage yang terdaftar di BEI periode tahun } \\
2016-2020\end{array}$ & 30 \\
\hline 2 & $\begin{array}{l}\text { Perusahaan manufaktur sektor food and } \\
\text { beverage yang mengalami rugi mulai tahun } \\
2016-2020\end{array}$ & (14) \\
\hline 3 & $\begin{array}{l}\text { Perusahaan manufaktur sektor food and } \\
\text { beverage yang tidak melakukan pembayaran } \\
\text { dividen kepada pemegang saham periode tahun } \\
2016-2020\end{array}$ & $(13)$ \\
\hline & Jumlah perusahaan yang diteliti & 3 \\
\hline & $\begin{array}{l}\text { Jumlah sampel penelitian } \\
\text { ( } 3 \text { perusahaan x } 5 \text { tahun) }\end{array}$ & 15 \\
\hline
\end{tabular}

(Sumber : data diolah, 2021)

Teknik pengumpulan data yang digunakan oleh peneliti adalah dokumentasi berupa Undang-undang, maupun peraturan-peraturan yang berlaku terkait penelitian, dan Laporan Keuangan Perusahaan dengan cara pengambilan data pada web resmi milik Bursa Efek Indonesia (IDX Indonesia Stock Exchange, 2021). Pengolahan data menggunakan alat bantu statistic yaitu SPSS versi 23. Variabel bebas (independent variable) dalam penelitian ini adalah perubahan tarif pajak, struktur modal, kebijakan dividen, sedangkan variabel terikat (dependent variable) dalam penelitian ini adalah harga saham. 
Tabel 3. Definisi Operasional dan Pengukuran Variabel

\begin{tabular}{|c|c|c|c|}
\hline Variabel & Definisi & Pengukuran & Literatur \\
\hline $\begin{array}{l}\text { Tarif Pajak } \\
\text { (X1) }\end{array}$ & $\begin{array}{l}\text { Tarif Pajak } \\
\text { merupakan } \\
\text { persentase tertentu } \\
\text { yang digunakan } \\
\text { untuk menghitung } \\
\text { besarnya pajak }\end{array}$ & $\begin{array}{l}\text { Perubahan tarif } \mathrm{PPh} \text { akan diukur } \\
\text { dengan Varibel dummy: } \\
\text { Dimana angka } 0 \text { menggambarkan } \\
\text { perusahaan yang menggunakan } \\
\text { tarif PPh yang mengacu UU PPh } \\
\text { No. } 36 \text { Tahun } 2008 \\
\text { Dimana angka } 1 \text { menggambarkan } \\
\text { perusahaan yang menggunakan } \\
\text { tarif PPh yang mengacu PP No. } 30 \\
\text { Tahun } 2020 \text {. }\end{array}$ & $\begin{array}{l}\text { (Qudriah } \\
\& \quad \text { Muid, } \\
\text { 2014), } \\
\text { (Resmi, } \\
\text { 2017) }\end{array}$ \\
\hline $\begin{array}{l}\text { Struktur } \\
\text { Modal (X2) }\end{array}$ & $\begin{array}{lr}\text { Struktur } & \text { modal } \\
\text { merupakan } & \\
\text { pemakaian } & \\
\text { liabilitas } & \text { jangka } \\
\text { panjang } & \text { kepada } \\
\text { ekuitas. } & \end{array}$ & $\begin{array}{l}\text { Ukuran struktur modal merujuk } \\
\text { pada Brigham dan Houston dalam } \\
\text { Marfuah dan Nurlaela } \\
\text { (2017)menggunakan total debt to } \\
\text { equity ratio: } \\
\text { DER = } \frac{\text { Total Debt }}{\text { Equity }}\end{array}$ & $\begin{array}{l}\text { (Mustofa, } \\
\text { Malavia, \& } \\
\text { Wahono, } \\
\text { 2019), } \\
\text { (Marfuah } \\
\& \\
\text { Nurlaela, } \\
\text { 2017) }\end{array}$ \\
\hline $\begin{array}{l}\text { Kebijakan } \\
\text { Dividen } \\
\text { (X3) }\end{array}$ & $\begin{array}{l}\text { Kebijakan dividen } \\
\text { adalah kebijakan } \\
\text { manajerial yang } \\
\text { dilakukan untuk } \\
\text { menetapkan } \\
\text { berapa besar laba } \\
\text { bersih yang tetap } \\
\text { ditahan untuk } \\
\text { cadangan investasi } \\
\text { tahun depan. }\end{array}$ & $\begin{array}{l}\text { Kebijakan dividen dapat diukur } \\
\text { menggunakan rasio Dividend } \\
\text { payout ratio (DPR) } \\
\text { DPR }=\frac{\text { Dividendper share }}{\text { earning per share }} \times 100 \%\end{array}$ & $\begin{array}{l}\text { (Verawati } \\
\& \\
\text { Puspitawa } \\
\text { ti, 2018), } \\
\text { (Silalahi \& } \\
\text { Manik, } \\
\text { 2019) }\end{array}$ \\
\hline $\begin{array}{l}\text { Harga } \\
\text { Saham (Y) }\end{array}$ & $\begin{array}{lr}\text { Harga } & \text { saham } \\
\text { merupakan harga } & \\
\text { yang muncul } \\
\text { sebagai hasil dari } \\
\text { pergerakan } \\
\text { penawaran dan } \\
\text { permintaan yang } \\
\text { muncul di pasar } \\
\text { efek. }\end{array}$ & $\begin{array}{l}\text { Harga saham diukur dari harga } \\
\text { penutupan atau closing price }(\mathrm{CP})\end{array}$ & $\begin{array}{l}\text { (Dewi \& } \\
\text { Suaryana, } \\
\text { 2013), } \\
\text { (Estiasih } \\
\text { et al., } \\
\text { 2020) }\end{array}$ \\
\hline
\end{tabular}

(Sumber : Data diolah, 2021)

Teknik analisis dalam penelitian ini menggunakan analisis Regresi Linier berganda dengan menggunakan $\mathrm{Uji} t$ dan $\mathrm{Uji} f$ yang bertujuan untuk menguji hubungan atau korelasi atau pengaruh lebih dari satu variabel bebas terhadap satu variabel terikat. 


\section{Hasil Dan Pembahasan \\ Hasil Penelitian \\ Pengujian Hipotesis}

Berikut ini hasil dari uji regresi linier berganda yang terdiri dari uji koefisien korelasi berganda, uji signifikansi regresi secara parsial (Uji t) dan uji signifikansi regresi secara simultan (Uji f) :

Tabel 4. Hasil Uji Koefisien Determinasi $\left(\mathrm{R}^{2}\right)$

\begin{tabular}{lcccc}
\hline \multicolumn{4}{c}{ Model Summary } \\
\hline Model & $\mathrm{R}$ & $\mathrm{R}$ & $\begin{array}{c}\text { Adjusted } \mathrm{R} \\
\text { Square }\end{array}$ & $\begin{array}{c}\text { Std. Error of the } \\
\text { Estimate }\end{array}$ \\
\hline 1 & $.755^{\mathrm{a}}$ & .570 & .452 & 2148.06033 \\
\hline
\end{tabular}

a. Predictors: (Constant), Kebijakan Deviden, Struktur Modal,

Perubahan Tarif Pajak

(Sumber : Output IBM SPSS Data diolah, 2021)

Berdasarkan tabel 4 dapat diketahui bahwa nilai $\mathrm{R}^{2}$ sebesar 0,570 maknanya perubahan tarif $\mathrm{PPh}$, struktur modal, dan kebijakan dividen mempengaruhi harga saham sebesar $57,0 \%$, sedangkan $43 \%$ sisanya dipengaruhi oleh variabel lain yang tidak diteliti dalam penelitian ini.

Tabel 5. Hasil Uji Signifikan Regresi Secara Parsial (Uji t)

\begin{tabular}{|c|c|c|c|c|c|c|}
\hline \multicolumn{2}{|c|}{ Model } & \multicolumn{2}{|c|}{$\begin{array}{l}\text { Unstandardized } \\
\text { Coefficients }\end{array}$} & \multirow{2}{*}{$\begin{array}{c}\text { Standardized } \\
\text { Coefficients }\end{array}$} & \multirow[t]{2}{*}{$\mathrm{t}$} & \multirow[t]{2}{*}{ Sig. } \\
\hline & & $\mathrm{B}$ & Std. Error & & & \\
\hline \multirow[t]{7}{*}{1} & (Constant) & 6784.720 & 1502.406 & & 4.516 & .001 \\
\hline & Perubahan & -2229.751 & 1429.746 & -.318 & -1.560 & .147 \\
\hline & Tarif Pajak & & & & & \\
\hline & Struktur & 4336.331 & 1216.311 & .718 & 3.565 & .004 \\
\hline & Modal & & & & & \\
\hline & Kebijakan & -16.988 & 20.503 & -.172 & -.829 & .425 \\
\hline & Deviden & & & & & \\
\hline
\end{tabular}

a. Dependent Variable: Harga Saham

(Sumber : Output IBM SPSS Data diolah, 2021)

Dari tabel 5, dapat diketahui hasil hipotesis ditemukan nilai uji t untuk variabel perubahan tarif pajak angka signifikansinya 0,147 lebih besar dari $\mathrm{a}=$ 0,05 maknanya perubahan tarif pajak tidak berpengaruh secara signifikan terhadap harga saham. Maka hipotesis 1 (H1) yang berbunyi "tarif pajak berpengaruh secara signifikan terhadap harga saham" ditolak.

Hasil hipotesis untuk variabel Struktur Modal, dengan angka signifikansi 0,004 lebih kecil dari $a=0,05$ dengan demikian, hipotesis 2 (H2) yang berbunyi "struktur modal berpengaruh secara signifikan terhadap harga saham" diterima.

Kebijakan dividen menunjukan nilai signifikansinya sebesar 0,425 lebih besar dari $a=0,05$ berarti hipotesis 3 (H3) yang berbunyi "kebijakan dividen berpengaruh secara signifikan terhadap harga saham" ditolak. 
Tabel 6. Hasil Uji Regresi Secara Simultan (Uji F)

ANOVAa

\begin{tabular}{llrrrrr}
\hline Model & & Sum of Squares & df & Mean Square & F & Sig. \\
\hline 1 & Regression & 67155288.538 & 3 & 22385096.179 & 4.851 & $.022^{\mathrm{b}}$ \\
& Residual & 50755794.795 & 11 & 4614163.163 & & \\
& Total & 117911083.333 & 14 & & & \\
\hline
\end{tabular}

a. Dependent Variable: Harga Saham

b. Predictors: (Constant), Kebijakan Deviden, Struktur Modal, Perubahan Tarif

Pajak

(Sumber : Output IBM SPSS 23, 2021)

Dari tabel 6 yang merupakan output IBM SPSS versi 23, dapat diketahui hasil pengujian hipotesis secara simultan (uji F) untuk variabel Perubahan Tarif Pajak, Struktur Modal, Kebijakan Dividen terhadap Harga Saham diperoleh angka probabilitas (sig.) 0,022 yaitu lebih kecil dari tingkat signifikansi a=0,05. Hal ini menunjukkan bahwa variabel Perubahan Tarif Pajak, Struktur Modal, Kebijakan Dividen secara simultan berpengaruh signifikan terhadap Harga Saham. Dengan demikian, hipotesis 4 (H4) yang berbunyi "Perubahan Tarif Pajak, Struktur Modal, Kebijakan Dividen terhadap Harga Saham berpengaruh secara simultan dan signifikan terhadap Struktur Modal" diterima.

\section{Pembahasan}

\section{Pengaruh Perubahan Tarif PPh Terhadap Harga Saham}

Hasil regresi untuk variabel perubahan tarif $\mathrm{PPh}$ yang ditunjukan pada tabel 5 memiliki pengaruh negative dan tidak signifikan dengan nilai signifikansinya 0,001. Hal tersebut berarti setiap ada penurunan tarif $\mathrm{PPh}$, maka tidak akan diikuti dengan kenaikan harga saham. Karena perubahan tarif $\mathrm{PPh}$ mengandung informasi yang kurang menarik bagi pihak-pihak yang mengambil keputusan, terutama yang berkaitan dengan harga saham. Penelitian ini membandingkan antara UU PPh No. 36 Tahun 2008 dengan PP No. 30 Tahun 2020 mengenai informasi kebijakan penurunan tarif $\mathrm{PPh}$ badan, tanpa adanya penurunan tarif $\mathrm{PPh}$ atas penerimaan deviden dan atau penurunan tarif $\mathrm{PPh}$ atas transaksi saham di $\mathrm{BEI}$, sehingga informasi ini kurang menarik minat investor untuk menanamkan dananya dalam bentuk saham kepada perusahaan. Hal tersebut membuat lemahnya permintaan dari pada penawaran terhadap saham perusahaan di $\mathrm{BEI}$, sehingga mempengaruhi pergerakan harga saham.

Hasil penelitian ini diperkuat oleh hasil penelitian yang telah dilakukan (Soalihin et al., 2019) dan (Putra \& Tjaraka, 2016). Namun hasil ini berbanding terbalik dengan hasil penelitian (Pranata et al., 2015) yang menyatakan "tarif pajak berpengaruh positif terhadap harga saham". Sekaligus membantah hasil penelitian (Suripto, 2019) yang menyatakan "tarif pajak berpengaruh positif dan signifikan terhadap harga saham".

\section{Pengaruh Struktur Modal Terhadap Harga Saham}

Pada tabel 5 struktur modal menunjukan nilai signifikansi $0,004<a=0,05$ dan Nilai koefisiennya sebesar 4336,331. Hal ini menunjukan adanya pengaruh positif secara signifikan antara struktur modal dengan harga saham. Berarti bila struktur modal semakin tinggi maka akan diikuti oleh kenaikan harga saham.

Hasil penelitian ini sejalan dengan teori (Brigham \& Houston, 2013) yang menjelaskan semakin tinggi risiko penggunaan hutang maka harga saham akan cenderung menurun. Penelitian yang dilakukan oleh (Estiasih et al., 2020) dan (Munira et al., 2018) juga mendukung hasil penelitian ini. Sedikit berbeda dengan 
(Neni, 2018) yang menunjukan "secara parsial DER berpengaruh positif dan tidak signifikan terhadap harga saham". Sedangkan hasil penelitian ini bertolak belakang dengan hasil penelitian yang dilakukan oleh (Mariana, 2016) dan (Hasanuddin, 2020) DER menunjukan pengaruh negative dan tidak signifikan.

\section{Pengaruh Kebijakan Dividen Terhadap Harga Saham}

Hasil hipotesis melalui uji t yang disajikan tabel 5 menunjukan kebijakan dividen memiliki signifikansi 0,425 $>a=0,05$. Hal ini memiliki arti bahwa secara parsial antara kebijakan dividen terhadap harga saham tidak ada pengaruh signifikan. Sedangkan kebijakan dividen memiliki koefisein sebesar -16,988 yang menunjukan bahwa adanya hubungan negative. Jika kebijakan dividen yang dilakukan melalui pembayaran saham atau Dividend payout ratio (DPR) yang menggambarkan besarnya uang tunai yang diberikan kepada investor. Maka kebijakan ini akan dianggap tidak produktif bagi investor bila nilai DPR rendah. Maknanya semakin rendah nilai DPR akan merugikan investor. Selain itu, penyebab tidak ada pengaruhnya antara kebijakan dividen terhadap harga saham karena calon investor akan lebih memilih mengikuti trend yang terjadi di pasar modal, karena pasar modal tidak merespon kebijakan pembagian dividen sehingga tidak mempengaruhi harga saham.

Hasil penelitian ini sejalan dengan teory yang dikemukakan oleh (Husnan \& Pudjiastuti, 2018) yang menyatakan sebagian investor menginginkan capital gain, sehingga tidak begitu mempedulikan akan pembagian dividen. Penelitian yang dilakukan (Mariana, 2016), juga mendukung hasil penelitian ini. Hasil berbeda ditunjukan oleh (Estiasih et al., 2020) menyatakan bahwa DPR berpengaruh secara signifikan terhadap harga saham. Sedangkan (Pranata et al., 2015) dalam penelitiannya menyatakan "kebijakan dividen berpengaruh positif terhadap harga saham".

\section{Pengaruh Perubahan Tarif Pajak, Struktur Modal, dan Kebijakan Dividen Terhadap Harga Saham}

Data dari tahun 2016-2020 pada uji F memberikan hasil angka signifikannya 0,022 lebih kecil dari $\mathrm{a}=0,05$. Hal ini menunjukkan bahwa ada pengaruh antara perubahan tarif pajak, struktur modal, kebijakan dividen terhadap harga saham secara simultan. Maknanya, setelah adanya perubahan tarif pajak, laba setelah pajak menjadi semakin besar karena pajak yang dibayar lebih rendah. Sama halnya dengan struktur modal, kemampuan perusahaan mengelola hutangnya dengan baik di masa pandemic, membuat perusahaan memiliki prospek yang baik. Karena perusahaan memiliki laba setelah pajak yang lebih besar dan kemampuan perusahaan dalam mengelola hutang yang baik, maka diambil kebijakan dividen untuk melakukan pembagian dividen. Hal ini menjadi bahan pertimbangan sebagian calon investor dalam melakukan penawaran terhadap harga saham. Dengan kata lain perubahan tarif pajak, struktur modal dan kebijakan dividen dapat mempengaruhi perubahan harga saham.

Kontribusi pengaruh dari semua variabel bebas terhadap variabel terikat dapat diketahui dari koefisien determinasi (R2) pada tabel 4 di atas yaitu 0,570. Hasil ini menunjukkan bahwa variabel bebas yang terdiri perubahan tarif pajak, struktur modal, kebijakan dividen mempunyai kontribusi sebesar $57 \%$ terhadap perubahan harga saham, sedangkan sisanya 43\% dipengaruhi oleh variabel lain yang tidak diteliti.

Penelitian ini mendukung teory yang dikemukakan oleh (Husnan \& Pudjiastuti, 2018) yang menyatakan bila tarif pajak atas deviden tinggi maka investor akan memilih perusahaan yang tidak terlalu sering memberikan kebijakan untuk membagikan dividen tunai kepada pemegang saham, hal tersebut dapat membuat investor merasa dikenakan pajak yang terlalu sering setiap pembagian 
deviden. Sebaliknya bila tarif pajak atas dividen rendah maka investor lebih suka memilih perusahaan yang sering memberikan deviden tunai kepada pemegang saham. Sehingga hal tersebut akan mempengaruhi harga saham perusahaan.

\section{Kesimpulan dan Saran}

Berdasarkan hasil analisis data penelitian dan pembahasan tentang pengaruh perubahan tarif pajak, struktur modal, kebijakan dividen terhadap harga saham, maka dapat disimpulkan perubahan tarif pajak dan kebijakan deviden tidak berpengaruh signifikan dan negative terhadap harga saham. Struktur modal berpengaruh signifikan dan positif terhadap harga saham. Hal ini berarti bahwa : (1) Tidak ada pengaruh antara perubahan tarif pajak dengan harga saham. Hal ini diartikan bahwa tinggi rendahnya tarif pajak tidak mampu mempengaruhi harga saham, karena informasi tentang perubahan tarif pajak yang dituang dalam PP No. 30 Tahun 2020 tidak mendapat respon yang positif terhadap harga saham. (2) Struktur modal dapat berpengaruh positif terhadap harga saham, semakin tinggi struktur modal akan diikuti dengan kenaikan harga saham. (3) Kebijakan dividen tidak mampu mempengaruhi harga saham. Mungkin hal ini disebabkan oleh kebijakan dividen melalui pembagian dividen di masa pandemic kurang berdampak secara langsung terhadap harga saham, karena beberapa investor berpendapat lebih senang melakukan transaksi saham yang dianggap lebih menguntungkan dimasa pandemic dari pada mendapatkan deviden tunai yang nantinya akan dikenakan pajak. (4) Secara keseluruhan perubahan tarif pajak, struktur modal, kebijakan dividen memiliki pengaruh terhadap harga saham. Karena sebagian calon investor mempertimbangkan tentang ketiga hal tersebut dalam mengambil keputusan terutama yang berkaitan dengan harga saham.

Penelitian ini memiliki keterbatasan yaitu sampel yang digunakan dalam penelitian hanya sampai tahun 2020 sedangkan aturan yang sesuai dengan indikator pengukuran variabel penelitian yang mengacu pada PP No. 30 Tahun 2020 masih ada perubahan tarif pajak lagi pada tahun 2022, selain itu perubahan tarif pajak hanya untuk badan bukan tarif pajak yang berkaitan langsung dengan pajak atas dividen atau pajak atas transaksi saham di bursa. Karena banyaknya perusahaan di sektor food and beverage yang tidak melakukan pembagian dividen di tahun 2020, sesuai dengan indikator pengukuran variabel kebijakan dividen melalui DPR maka sampel dalam penelitian ini sangat terbatas.

Saran yang direkomendasikan oleh peneliti bagi perusahaan dapat memanfaatkan kebijakan pemerintah terkait perpajakan, sekecil apapun manfaatnya dan mengelola struktur modal secara baik dengan cara membagi resiko kerugian dalam mengelola perusahaan dengan memanfaatkan modal asing atau hutang sebagai pendanaan dimasa pandemic. Stategi yang baik dalam kebijakan deviden dalam masa pandemic yaitu untuk menahan saldo laba sebagai penambah modal dalam mengelola perusahaan dari pada dibagikan dalam bentuk dividen. Kecerdasan manajemen dalam mengambil keputusan dan mengelola peluang dimasa pandemic akan menarik kepercayaan investor, hal ini akan meningkatkan harga saham dengan sendirinya. Saran bagi peneliti selanjutnya yaitu bisa melanjutkan penelitian ini dengan merubah indikator pengukuran variabel yang semula dummy dengan rasio dan atau menambah sampel penelitian sesuai dengan tahun yang tersaji dalam peraturan perpajakan yang berlaku.

\section{Daftar Pustaka}

Alfandia, N. S. (2018). Pajak dan Struktur Modal Perusahaan Manufaktur di Indonesia. Jurnal BAKI, Berkala Akuntansi Dan Keuangan Indonesia, 03(01), 17-34. 
Ayem, S., \& Fatimah, A. (2018). Pengaruh rasio keuangan dan penurunan tarif pajak terhadap pembayaran dividen. Jurnal Riset Akuntansi Tirtayasa, 03(01).

Brigham, E. F., \& Houston, J. F. (2013). Dasar-Dasar Manajemen Keuangan Buku 1 (11th ed.). Jakarta: Salemba Empat.

Dewi, P. D. A., \& Suaryana, I. G. N. . (2013). Pengaruh EPS,DER, dan PBV Terhadap Harga Saham. E-Jurnal Akuntansi Universitas Udayana, 1(4), 215229.

Estiasih, S. P., Prihatiningsih, E., \& Fatmawati, Y. (2020). Dividend Payout Ratio , Earning Per Share, Debt To Equity Ratio Terhadap Harga Saham pada Perusahaan LQ45. Jurnal Akuntansi Dan Pajak, 21(1), 205-212.

Fahmi, I. (2018). Pengantar Manajemen Keuangan Teori dan Soal Tanya Jawab. (M. A. Djalil, Ed.). Bandung: Alfabeta.

Faisal, M. (2012). Manajemen Keuangan Internasional. Jakarta: Salemba Empat.

Febriani, A. D., \& Kristanti, F. T. (2020). Determinan Struktur Modal Perusahaan Infrastruktur, Utilitas, Dan Transportasi. E-Jurnal Ekonomi Dan Bisnis Universitas Udayana, 9(3), 275-302.

Harmono. (2018). Manajemen Keuangan Berbasis Balanced Scorecard Pendekatan Teori, Kasus, dan Riset Bisnis. (R. Rachmatika, Ed.). Jakarta: Bumi Aksara.

Hasanuddin, R. (2020). Pengaruh Struktur Modal, Ukuran Perusahaan dan Profitabilitas Terhadap Harga Saham Pada Perusahaan Makanan Dan Minuman Yang Terdaftar Di Bursa Efek Indonesia. Jurnal Equilibrum, 1(No. 2 1), 54-63.

Husnan, S., \& Pudjiastuti, E. (2018). Dasar - Dasar Manajemen Keuangan (Edisi Ketu). Yogyakarta: UPP STIM YKPN.

IDX Indonesia Stock Exchange. (2021). PT Bursa Efek Indonesia. Retrieved from https://www.idx.co.id/

Kamaludin, \& Indriani, R. (2012). Manajemen Keuangan Konsep Dasar dan Penerapannya. Bandung: Mandar Maju.

Kementerian Sekretariat Negara Republik Indonesia. (2008). Undang-Undang Republik Indonesia Nomor 36 Tahun 2008 Tentang Perubahan Keempat Atas Undang-Undang Nomor 7 Tahun 1983 Tentang Pajak Penghasilan. Jakarta. Retrieved from https:// pajak.go.id/

Kementerian Sekretariat Negara Republik Indonesia. Peraturan Pemerintah Pengganti Undang-Undang Republik Indonesia Nomor 1 Tahun 2020 Tentang Kebijakan Keuangan Negara dan Stabilitas Sistem Keuangan Untuk Penanganan Pandemi corona virus disease 2019 (Covid-19) dan/atau dalam rangka menghadapi ancaman yang (2020). Indonesia.

Kementerian Sekretariat Negara Republik Indonesia. Peraturan Pemerintah Republik Indonesia Nomor 30 Tahun 2020 Tentang Penurunan Tarif Pajak Penghasilan Bagi Wajib Pajak Badan Dalam Negeri Yang Berbentuk Perseroan Terbuka (2020). Indonesia.

Marfuah, S. A., \& Nurlaela, S. (2017). Pengaruh Ukuran Perusahaan, Pertumbuhan Asset, Profitabilitas dan Pertumbuhan Penjualan Terhadap Struktur Modal Perusahaan Cosmetics and Household di Bursa Efek Indonesia. Jurnal Akuntansi Dan Investasi, 18(01), 16-30.

Mariana, C. (2016). Pengaruh Kinerja Keuangan dan Kebijakan Dividen Terhadap Harga Saham. Jurnal Ilmiah Akuntansi, 1(1), 22-42.

Muhonis, M. G., \& Susanti, M. (2021). Pengaruh ROA, DER, SIZE , dan EPS terhadap harga saham perusahaan manufaktur. Jurnal Multiparadigma Akuntansi, III(2), 703-711.

Munira, M., Merawati, E. E., \& Astuti, S. B. (2018). Pengaruh ROE dan DER Terhadap Harga Saham Perusahaan Kertas di Bursa Efek Indonesia. Journal 
Of Applied Business and Economics, 4(3), 191-205.

Musthafa. (2017). Manajemen Keuangan. Yogyakarta: Andi Offset.

Mustofa, A., Malavia, R. M., \& Wahono, B. (2019). Pengaruh Struktur Modal, Profitabilitas dan Ukuran Perusahaan Terhadap Nilai Perusahaan. E-Jurnal Riset Manajemen, 17(8), 53-66.

Neni. (2018). Analisis Pengaruh Struktur Modal dan Profitabilitas Terhadap Harga Saham Pada Perusahaan Manufaktur Sektor Aneka Industri yang Terdaftar di Bursa Efek Indonesia. Universitas Sumatera Utara.

Pranata, G., Purnamawati, I. G. A., \& Adiputra, I. M. P. (2015). Pengaruh Tarif dan Kebijakan Dividen Terhadap Harga Saham. E-Journal S1 Ak Universitas Pendidikan Ganesha, 3(1).

Putra, G. R., \& Tjaraka, H. (2016). Pengaruh Perubahan Tarif Pajak Penghasilan Badan Terhadap Return Saham Dengan Liabilitas Pajak Tangguhan Sebagai Variabel Intervening Pada Perusahaan Manufaktur Yang Terdaftar di BEI. Jurnal InFestasi, 12(1), 98-108.

Qudriah, D. N., \& Muid, A. (2014). Pengaruh Perubahan Tarif Pajak Penghasilan Wajib Pajak Badan dan Karakteristik Perusahaan Terhadap Struktur Modal Perusahaan. Diponegoro Journal Of Accounting, 3(2), 1-9.

Rahayu, P. (2019). PERPAJAKAN Disesuaikan dengan Peraturan Perpajakan Terbaru. Sidoarjo: Indomedia.

Resmi, S. (2017). Perpajakan (Teori \& Kasus). (M. Masykur, Ed.) (1st ed.). Jakarta Selatan: Salemba Empat.

Silalahi, E., \& Manik, E. S. (2019). Pengaruh Dividen Payout Ratio, Debt Ratio dan Return On Asset Terhadap Harga Saham Pada Perusahaan Manufaktur Yang Terdaftar di Bursa Efek Indonesia. JRAK, 5(1), 49-70.

Soalihin, I., Susyanti, J., \& Salim, A. (2019). Pengaruh Pertumbuhan Perusahaan, Total Asset Turnover (TATO), Earning Per Share (EPS) dan PPh Badan Terhadap Harga Saham. E-Jurnal Ilmiah Riset Manajemen, 8(17), 38-59.

Suandy, E. (2016). Perencanaan pajak (6th ed.). Jakarta: Salemba Empat.

Sulia. (2017). Analisis faktor - faktor yang mempengaruhi harga saham pada perusahaan LQ45 yang terdaftar di bursa efek indonesia. Jurnal Wira Ekonomi Mikroskil, 7(2), 129-140.

Sulindawati, N. luh gede E., Yuniarta, G. A., \& Purnamawati, I. G. A. (2017). Manajemen Keuangan Sebagai Dasar Pengambilan Keputusan Bisnis. Depok: Rajawali Pers.

Suripto. (2019). Pengaruh Tarif Pajak, Earning Per Share Dan Pertumbuhan Penjualan Terhadap Harga Saham (Studi Empiris Perusahaan Manufaktur Yang Terdaftar Di Bursa Efek Indonesia. Jurnal Renaissance, 4(01), 479-494.

Utami, L. N. S., \& Widanaputra, A. A. G. P. (2017). Pengaruh Perubahan Tarif Pajak, Profitabilitas, Likuiditas dan Ukuran Perusahaan Terhadap Struktur Modal Pada Perusahaan Manufaktur Di Bursa Efek Indonesia Pada Tahun 2008-2012. E-Jurnal Ekonomi Dan Bisnis Universitas Udayana, 5, 2047-2070.

Verawati, E., \& Puspitawati, L. (2018). Pengaruh Profitabilitas Terhadap Struktur Modal Serta Dampaknya Pada Kebijakan Deviden. Universitas Komputer Indonesia.

Viriany, \& Kristian. (2021). Faktor Faktor Yang Mempengaruhi Kebijakan Dividen. Jurnal Multiparadigma Akuntansi, III(2), 490-496.

Widanastiti, S. A., \& Rahayu, P. (2020). Pengaruh Struktur Modal , Struktur Aset Dan Struktur Kepemilikan Terhadap Risiko Keuangan Pada Perusahaan Property Dan Real Estate. Jurnal Cendekia Akuntansi, 1(1), 9-17. 